\title{
High Protein Milk Intervention in Malnourished Children and Its Effect on Weight Gain and Renal Function
}

\author{
Clara Meliyanti Kusharto ${ }^{1 *}$, Karina Rahmadia Ekawidyani' ${ }^{1}$ Ikeu Tanziha ${ }^{1}$, \\ Budi Setiawan $^{1}$, Risti Rosmiati ${ }^{2}$, Andi Muh Asrul Irawan ${ }^{3}$ \\ ${ }^{1}$ Department of Community Nutrition, Faculty of Human Ecology, IPB University, \\ Bogor 16680, Indonesia \\ ${ }^{2}$ Study Program of Nutrition, Department of Family Welfare Education, Faculty of Engineering, \\ State University of Medan 20211, Indonesia \\ ${ }^{3}$ Study Program of Nutrition, Faculty of Science and Technology, University of Al Azhar Indonesia, \\ Jakarta 12110, Indonesia
}

\begin{abstract}
This study aimed to determine the effect of high-protein milk intervention on weight gain and renal function in malnourished children. This research is a randomized controlled trial (RCT). A total of 52 wasting children (BAZ $-3<\mathrm{SD}<-2$ ) aged 3-12 years were selected by simple random sampling from five primary schools (6-12 years) and two Community Health Center (children below 6 years). Subjects were divided into two groups; control group (26) and intervention group (26). The intervention group was given high-protein milk (HPM) $3 \times 25$ g each day for 12 weeks. Body weight, serum creatinine, and urea were measured at week 0 (baseline), $6^{\text {th }}$ (midline), and $12^{\text {th }}$ (endline). The study showed that the body weight of the intervention group significantly increased by $1.54 \mathrm{~kg}$ after 12 weeks of highprotein milk consumption. Serum urea and creatinine levels in the intervention group also significantly increased $(\mathrm{p}<0.05)$. The increase in serum urea and creatinine levels in the intervention group were still within the normal range (normal serum urea level $15-43 \mathrm{mg} / \mathrm{dl}$ and normal creatinine level $0.6-1.2 \mathrm{mg} /$ dl). This suggests that significant increases in urea and creatinine levels of the intervention group were normal because of increased protein intake and body muscle mass and it did not lead to renal function abnormalities.
\end{abstract}

Keywords: body weight, creatinine, high-protein milk, malnourished, urea

\section{INTRODUCTION}

Nutrition plays an important role in achieving quality of human resources. Nutrition problems at an early age can result in the risk of various degenerative diseases during adulthood (Barker Theory) (Dover 2009). Data from the Basic Health Research (MoH 2013) indicated that the prevalence of malnutrition, based on Body Mass Index for Age z-score (BAZ) in Indonesian children aged 5-12 years was $11.2 \%$, consisted of $4 \%$ severe wasting and $7.2 \%$ wasting.

One strategy to overcome wasting in childhood is to increase the level of protein intake. Protein intake affects the body composition through changes in protein synthesis. A highprotein diet can lead to increase positive protein balance which leads to increase protein synthesis. Protein serves as a body-builder, body-maintaining agent, and maintains resistance to disease (Istiany \& Rusilanti 2013). Do Thi et al. (2009) explained that milk supplementation could increase body weight due to high quality proteins, fats, and a number of essential micronutrients content in milk, which might be lacking in the regular diet.

Milk is included in the five most popular beverages as breakfast among children aged 6-12 years in Indonesia (Hardinsyah \& Aries 2012). Research conducted by Damayanthi et al. (2010) in elementary school children in urban Bogor showed that more than $90 \%$ of primary school students consume milk every day with an average consumption of more than twice a day. However, the type of milk mostly consumed by children is sweetened condensed milk (Hardinsyah \& Aries 2012). Sweetened condensed milk contains a low protein $(8 \%)$ but has a high sugar content (54\%).

Therefore, the provision of high-protein milk (HPM) is one of the methods proposed to increase protein consumption, especially in malnourished children to increase body weight. But

"Corresponding Author: tel: +62811116178, email:kcl_51@yahoo.co.id 
long term high protein intake can increase metabolic burden for the kidney that can leads to renal function impairment (Campbell et al. 2007). The decreased in renal function is characterized by elevation of urea and creatinine levels. Urea is the result of protein decomposition, especially from food. Therefore, the level of urea is influenced by the amount of protein intake. If creatinine levels increased 1-2 mg/dl from the normal level, it indicates that glomerular filtration rate (GFR) decrease $\pm 50 \%$ (Badye et al. 2016).

Considering the potential gain and negative effect of HPM, this study aims to determine the effect of HPM on weight gain and renal function in malnourished children.

\section{METHODS}

\section{Design, location, and time}

This research is an experimental research with randomized controlled trial (RCT) design. This research was conducted in elementary students of five primary schools and two Community Health Centers in Bogor. Blood serum analysis was performed at Regional Health Laboratory of Bogor. The study was conducted from August 2016 to January 2017.

\section{Materials and tools}

The main material used was commercial HPM (Appeton Weight Gain 3-12 Years). The tools used during the intervention are weight scales, microtoise, food recall form, milk consumption compliance form, and food model. Equipment for blood collection were tubes, alcohol swabs, and syringes.

\section{Sampling}

There were two groups in this study, the control group and the intervention group. The control group received nutrition education without HPM and intervention group received nutrition education and HPM. Each group consists of 30 malnourished children.

The inclusion criteria for the study were healthy children aged 13-12 years old with BAZ score between $-3<\mathrm{SD}<-2 \mathrm{SD}$, able to respond to verbal instructions without difficulties, parents or guardians agree to sign informed consent, and have been given an explanation of the research. Subjects were excluded if they have had history of milk allergies metabolic syndrome, kidney disease, regularly take medications that affect body composition, take part in other studies, and unable to fully take part in this study. Subjects aged
3-5 years old were recruited from Community Health Centers, while subjects aged 6-12 years old were recruited from primary schools.

\section{Steps of intervention}

The first stage was baseline data collection, data collected in this stage were sex, age, food consumption, weight, height, and renal function (urea and creatinine). The second stage was the provision of HPM intervention. Products were distributed every 12 days (each subject received 2 cans (@900 g). The intervention group was given daily HPM of $3 \times 25 \mathrm{~g}$ (75 g/day) for 12 weeks. Every $25 \mathrm{~g}$ of milk contains $120 \mathrm{kcal}$ of energy, 7 $\mathrm{g}$ protein, $6 \mathrm{~g}$ of fat and $10 \mathrm{~g}$ of carbohydrate. The dosage of the HPM was based on the serving size written on the can.

Milk consumption was monitored and evaluated every week to assess compliance. HPM consumption were recorded every day, under five children and elementary school students were monitored by cadres and school teachers, respectively. Counseling /nutrition education and the introduction of intervention products are given once a week as an effort to improve compliance and to maintain subject participation in research activities. The third stage was the measurement of weight gain and renal function in relation to HPM administration. Body weight, serum urea, and creatinine levels were measured at week $6^{\text {th }}$ and $12^{\text {th }}$ of intervention.

\section{Data analysis}

Individual characteristics were described descriptively, presented in percent (\%), mean (mean), and standard deviation. Repeated ANOVA analysis was used for different test of all variables in each group before and after intervention (baseline, midline, and endline). Independent ttest was used for the analysis of the difference between intervention and control group on all variables.

\section{RESULTS AND DISCUSSION}

\section{Weight gain}

There were 30 subjects at the initial stage for each group and four subjects were drop out due to experiencing nausea and diarrhea after consuming milk for each group. Total subjects who completed the study were 52 children. Intervention and the control group each consisted of 26 children with $46.2 \%$ boys and $53.8 \%$ girls. The mean age was $9.5 \pm 1.80$ and $9.95 \pm 1.66$ years in control and intervention group, respectively. 
At the baseline, the body weight in the control group and the intervention group showed no significant difference $(p=0.312)$. Six weeks after receiving high protein milk intervention, the body weight of intervention group increased significantly compared to control group $(\mathrm{p}=0.009)$. At week $12^{\text {th }}$, the body weight of the intervention group increased significantly to $1.54 \mathrm{~kg}$. The weight gain $(\triangle \mathrm{BB} 2)$ of the intervention group was almost doubled than the control group. Measurement of body weight is presented in Table 1 .

Body weight can reflect the increase or decrease of all existing tissues in the body such as bones, muscles, organs, and body fluids (Gibson 2005) therefore the nutritional status and development of children can be measured. Supplementary feeding in malnourished children with a higher proportion of energy from protein is associated with greater weight gain (Pimpin et al. 2015). The intervention product (HPM) in this study has $480 \mathrm{kcal} / 100 \mathrm{~g}$ energy content with $24 \%$ energy derived from protein $(28 \mathrm{~g} / 100 \mathrm{~g})$. The intake of HPM meets $17.1 \%-22.5 \%$ Recommended Daily Allowance (RDA) of energy and $37.5 \%-60.0 \%$ RDA of protein for children aged 3-12 years.

Adequate protein intake plays an important role, especially during the growth period. Protein plays a role in forming the major structural components of all cells in the body, maintaining established cells or tissues, and for replacing damaged cells (Wu 2016). A high-protein diet has been reported to increase positive protein balance (reduced protein degradation and increased protein synthesis) (Setiowati 2012). Whereas postprandial protein synthesis depends on the rate of protein absorption.

Milk is a source of high bioavailable protein (Aimutis 2004). High protein milk contains two major protein components, casein $(80 \%)$ and whey protein (20\%) (Pal et al. 2010). Whey protein is easier and faster to digest than casein and has a high amino acid profile (Jakubowicz \& Froy 2013). The whey proteins contained in milk is $\alpha$-lactalbumin $(\alpha$-LA, 20\%), $\beta$-lactoglobulin
$(\beta-\mathrm{Lg}, 50 \%)$, serum albumin (BSA, 10\%), immunoglobulins $(10 \%)$ and peptones protease. Whey protein content in milk is associated with increased muscle mass and growth hormone Insulin-like Growth Factor (IGF)-1 which stimulates protein synthesis by activating mTOR signal (Mitchel et al. 2015). Abargouei et al. (2012) also explained that dairy consumption has positive effect on body weight.

\section{Intake of energy and protein (other than HPM) and compliance level}

Weight gain is closely related to the amount of energy and protein intake per day from HPM and other daily food consumption. The energy and protein intake derived from HPM associated with the level of compliance level of subject consumption. Compliance analysis of subjects showed that $88.5 \%$ had high compliance level $(>70 \%)$ and $11.5 \%$ had moderate compliance level (50-70\%).

Energy intake of control group during the study period did not change significantly $(p=0.559)$ while energy intake of intervention group at 12 weeks increased significantly. The increase in energy intake $(\Delta 2)$ of intervention group did not differ significantly with the control group ( $\mathrm{p}=0.149)$.

Daily protein intake from food (other than HPM) during 12 weeks intervention in both groups did not differ significantly $(p>0.05)$. The results of energy and protein intake analysis are available in Table 2. Energy and protein intake (other than HPM) is not considered to be a confounding variable in weight gain $(\triangle B B 1$ and $\triangle B B 2$ ) since mean of energy and protein intake between control and intervention groups did not differ significantly and subjects had high compliance level of HPM.

\section{Renal function}

Serum urea and creatinine measurements can be used to evaluate renal function. The results of serum urea and creatinine analysis are presented in Table 3. Measurements of urea and

Table 1. Measurement of body weight

\begin{tabular}{|c|c|c|c|c|c|c|}
\hline \multirow{2}{*}{ Group } & \multicolumn{3}{|c|}{ Mean body weight $(\mathrm{kg})$} & \multirow{2}{*}{ p-value ${ }^{2}$} & \multirow{2}{*}{$\Delta \mathrm{BB} 1$} & \multirow{2}{*}{$\Delta \mathrm{BB} 2$} \\
\hline & Baseline & Midline & Endline & & & \\
\hline Control & $22.18 \pm 4.19^{\mathrm{a}}$ & $22.91 \pm 4.28^{b}$ & $23.15 \pm 4.41^{\mathrm{b}}$ & $0.000 *$ & 0.73 & 0.90 \\
\hline Intervention & $21.07 \pm 3.58^{\mathrm{a}}$ & $22.38 \pm 3.86^{\mathrm{b}}$ & $22.62 \pm 3.91^{\mathrm{c}}$ & $0.000 *$ & 1.30 & 1.54 \\
\hline p-value ${ }^{1}$ & 0.312 & 0.641 & 0.646 & & $0.009 *$ & $0.021 *$ \\
\hline
\end{tabular}

${ }^{1}$ Independent t-test; ${ }^{2}$ repeated ANOVA test for baseline, midline and endline data; *statistically significant at $\alpha<0.05$; The mean value followed by superscript letter in the same column does not differ significantly; $\Delta 1=($ baseline-midline); $\Delta 2=($ baseline-endline $)$ 
Kusharto et al.

Table 2. Energy and protein intake (other than High Protein Milk)

\begin{tabular}{lcccccc}
\hline \multicolumn{1}{c}{ Group } & Baseline & Midline & Endline & $\mathrm{p}^{2}$ & $\Delta 1$ & $\Delta 2$ \\
\hline Energy (kcal) & & & & & \\
Control & $1117 \pm 193^{\mathrm{a}}$ & $1199 \pm 401^{\mathrm{a}}$ & $1153 \pm 252^{\mathrm{a}}$ & 0.559 & 82.5 & 36.4 \\
Intervention $^{\text {p-value }}$ & $1129 \pm 271^{\mathrm{a}}$ & $1223 \pm 392^{\mathrm{ab}}$ & $1295 \pm 318^{\mathrm{bc}}$ & $0.039^{*}$ & 93.7 & 166 \\
Protein (g) $^{\text {Control }}$ & 0.855 & 0.834 & 0.081 & & 0.925 & 0.149 \\
Intervention $^{\text {p-value }}$ & & & & & \\
\end{tabular}

${ }^{1}$ Independent $\mathrm{t}$-test; ${ }^{2}$ repeated ANOVA test for baseline, midline and endline data; ${ }^{*}$ statistically significant at $\alpha<0.05$; The mean value followed by superscript letter in the same column does not differ significantly; $\Delta 1=$ (baseline-midline); $\Delta 2=($ baselineendline)

Tabel 3. Measurement of serum urea dan creatinine level

\begin{tabular}{|c|c|c|c|c|c|c|}
\hline Group & Baseline & Midline & Endline & p-value ${ }^{2}$ & $\Delta 1$ & $\Delta 2$ \\
\hline \multicolumn{7}{|l|}{ Urea (mg/dl) } \\
\hline Control & $24.6 \pm 6.19^{\mathrm{a}}$ & $24.6 \pm 4.56^{\mathrm{a}}$ & $24.4 \pm 4.65^{\mathrm{a}}$ & 0.983 & -0.03 & -0.23 \\
\hline Intervention & $22.6 \pm 4.48^{\mathrm{a}}$ & $29.5 \pm 6.46^{\mathrm{b}}$ & $29.4 \pm 7.31^{\mathrm{b}}$ & $0.000 *$ & 6.92 & 6.80 \\
\hline p-value ${ }^{1}$ & 0.189 & $0.002 *$ & $0.005^{*}$ & & $0.000^{*}$ & $0.001 *$ \\
\hline \multicolumn{7}{|c|}{ Creatinine (mg/dl) } \\
\hline Control & $0.65 \pm 0.11^{\mathrm{a}}$ & $0.79 \pm 0.18^{b}$ & $0.60 \pm 0.13^{\mathrm{a}}$ & $0.000^{*}$ & 0.13 & -0.05 \\
\hline Intervention & $0.67 \pm 0.10^{\mathrm{a}}$ & $0.72 \pm 0.14^{\mathrm{a}}$ & $0.71 \pm 0.10^{\mathrm{a}}$ & 0.318 & 0.05 & 0.03 \\
\hline $\mathrm{p}$-value ${ }^{1}$ & 0.550 & 0.151 & $0.005^{*}$ & & 0.068 & $0.049 *$ \\
\hline
\end{tabular}

${ }^{1}$ Independent t-test; ${ }^{2}$ repeated ANOVA test for baseline, midline and endline data; *statistically significant at $\alpha<0.05$; The mean value followed by superscript letter in the same column does not differ significantly; $\Delta 1=$ (baseline-midline); $\Delta 2=($ baselineendline)

creatinine levels before intervention (baseline) in control and intervention groups showed no significant differences $(p>0.05)$. Urea level in the intervention group increased significantly after six weeks of intervention $(\Delta 1)(\mathrm{p}<0.05)$ while the creatinine level increased significantly at week 12th $(\Delta 2)(\mathrm{p}>0.05)$. These findings were similar to a meta-analysis comparing high vs. normal/ low protein diets on renal function in subjects without chronic kidney disease (Schwingshackl \& Hoffmann 2014). The study found that high protein diets were associated with increase glomerular filtration rate (GFR) and serum urea.

Urea is the end product of protein catabolism and amino acids produced by the liver. Urea is distributed through intracellular and extracellular fluids into the blood. Level of urea in the blood reflects the balance of urea production and excretion. Urea in blood is a major element that results from decomposition process of proteins and other chemicals that contain nitrogen. Urea and other nitrogen-rich waste products, normally removed from blood vessels through the kidneys. The reference value of normal serum urea level is $15-43 \mathrm{mg} / \mathrm{dl}$ (Suryawan et al. 2016). Elevated blood urea may occur in fever, high-protein diets, corticosteroid therapy, gastrointestinal bleeding due to increased protein catabolism (Gowda et al. 2010).

Increased urea level in the intervention group is thought to be due to high protein intake. Protein from HPM contributed 37.5\%-60\% of RDA in children aged 3-12 years. However, protein was also obtained from daily food consumption (other than HPM) in the amount $72.8 \%$ $-116 \%$ of RDA.

High protein supplementation is thought to cause an increased in muscle mass characterized by weight gain in the intervention group. The outcome of muscle cells metabolism will be converted into creatinine in the blood. Creatinine is the result of muscle phosphate creatin breakdown that is produced constantly by the body. Creatinine level depends on muscle mass rather than muscle activity or protein metabolic rate (Baxmann et al. 2008). Normal creatinine references in children are $0.6-1.2 \mathrm{mg} / \mathrm{dl}$ (Ghasemi et al. 2015). 
The increased urea and creatinine levels in the intervention group were still within the normal range. This suggests that significant increase in urea and creatinine levels of intervention group did not lead to impairment in renal function. Increased urea and creatinine level was normal due to increase in protein intake and body muscle mass.

\section{CONCLUSION}

High-protein milk intervention three times per day ( $75 \mathrm{~g} /$ day) for 12 weeks can promote significant weight gain $(\mathrm{p}<0.05)$. High-protein milk intervention could cause increased serum urea and creatinine levels but did not interfere with renal function, indicated by the level of serum urea and creatinine still within the normal range. Thus consumption of high-protein milk should be done properly (not excessive) and maintaining healthy diet according to balanced nutrition guidelines is suggested.

\section{ACKNOWLEDGMENT}

This research was supported by the Kotra Pharma (M) SDN BHD under MoU between Kotra Pharma (M) SDN BHD Malaysia and Faculty of Human Ecology, IPB University (April $5,2016)$. We thanks SDN Sindangbarang 1, SDN Sindangbarang 2, SDN Sindangbarang 3, SDN Sindangbarang 3, SDN 4 Babakan Dramaga, Public Health Center Ciherang and Sukawening, Bogor for their supporting in this research. We delivered special thanks to Ms. Amalia Rahma for her assistance with statistical analysis. The authors have no conflicts of interest.

\section{REFERENCES}

Aimutis WR. 2004. Bioactive properties of milk proteins with particular focus on anticariogenesis. J Nutr 134(4):989S-995S

Abargouei AS, Janghorbani M, Salehi-Marzijarani M, Esmaillzadeh A. 2012. Effect of dairy consumption on weight and body composition in adults: a systematic review and meta-analysis of randomized controlled clinical trials. Int J Obes 36(1):1485-1493.

Badve SV, Palmer SC, Hawley CM, Pascoe EM, Strippoli GFM, Johnson DW. 2016. Glomerular filtration rate decline as a surrogate end point in kidney disease progression trials. Nephrol Dial Transpl 31(9):14251436.

Baxmann AC, Ahmed MS, Marques NC, Menon VB, Pereira AB, Kirsztajn GM, Heilberg

J. Gizi Pangan, Volume 14, Number 1, March 2019
IP. 2008. Influence of muscle mass and physical activity on serum and urinary creatinine and serum Cystatin C. Clin J Am Soc Nephrol 3(2):348-354.

Campbell B, Kreiders R, Ziegenfuss T. 2007. International society of sport nutrition position stand: protein and exercise. Int J Sport Nutr Exerc Metab 4(1):1550-2783.

Damayanthi E, Dwiriani CM, Kustiyah L, Briawan D. 2010. Food habit among elementary school children in urban bogor. J Gizi Pangan 5(3):158-163.

Do Thi KL, Bui TN, Nguyen CK, Le Thi H, Nguyen TQN, Nguyen TH, Kiers J, Shigeru Y, Biesebeke RT. 2009. Impact of milk consumption on performance and health of primary school children in rural Vietnam. Asia Pac J Clin Nutr 18(3):326-334.

Dover GJ. 2009. The Barker hypothesis: how pediatricans will diagnose and prevent common adult-onset disease. Transaction Of The American Clinical and Climatological Association 120:199-207.

Ghasemi A, Azimzadeh I, Afgan M, Momenan AA,Bagheripour F, Azizi F. 2015. Pediatric reference values for serum creatinine and estimated glomerular filtrationrate in iranian: Tehran lipid and glucose study. Iranian Medicine 18(11):753-759.

Gibson RS. 2005. Principles of Nutritional Assessment. New York: Oxford University Press.

Gowda S, Desai PB, Kulkarni SS, Hull VV, Math AAK, Vernekar SN. 2010. Markers of renal function tests. N Am J Med Sci 2(4):170-173.

Hardinsyah, Aries M. 2012. Jenis pangan sarapan dan perannya dalam asupan gizi harian anak usia 6-12 tahun di Indonesia. J Gizi Pangan 7(2):89-96.

Istiany A, Rusilanti. 2013. Gizi Terapan. Bandung: PT Remaja Rosdakarya.

Jakubowicz D, Froy O. 2013. Biochemical and metabolic mechanisms by which dietary whey protein may combat obesity and Type 2 diabetes. J Nutr Biochem 24(1): 1-5.

[MoH] Ministry of Health. 2013. National Basic Health Report (Riskesdas). Jakarta: Kementerian Kesehatan.

Mitchell CJ, McGregor RA, D'Souza RF, Thorstensen EB, Markworth JF, Fanning AC, Poppitt SD, Cameron-Smith D. 2015. Consumption of milk protein or whey protein results in a similar increase in muscle protein synthesis in middle aged men. Nutrients 7(10):8685-8699. 
Pal S, Ellis V, Dhaliwal S. 2010. Effects of whey protein isolate on body composition, lipids, insulin, and glucose in overweight and obese individuals. Br J Nutr 104(5):716723.

Pimpin L, Jebb S, Johnson L, Wardle J, Ambrosini GL. 2015. Dietary protein intake is associated with body mass index and weight up to $5 \mathrm{y}$ of age in a prospective cohort of twins. Am J Clin Nutr 103(2):389-397.

Schwingshackl L, Hoffmann G. 2014. Comparison of high vs. normal/low protein diets on renal function in subjects without chronic kidney disease: a systematic review and meta-analysis. PLOS One 9(5):1-13.
Setiowati A. 2012. Pengaruh diet tinggi protein terhadap indeks massa tubuh, persen lemak tubuh, kekuatan otot dan kecepatan pada atlet [thesis]. Semarang: Universitas Diponegoro.

Suryawan DGA, Arjani IAMS, Sudarmanto IG. 2016. Gambaran kadar urea dan kreatinin serum pada pasien gagal ginjal kronis yang menjalani terapi hemodialisis di RSUD Sanjiwani Gianyar. Meditory 4(2):145153.

Wu G. 2016. Dietary protein intake and human health. Food Funct 7(3):1251-65 